\title{
L’ocupació abans de la COVID-19
}

\author{
Rafael Allepuz Capdevila \\ Departament d'Economia Aplicada. Universitat de Lleida
}

El treball és la principal activitat de la nostra vida, a la que dediquem més hores i de la qual depenem econòmicament. Les nostres condicions de vida depenen de les circumstàncies en les que treballem i cóm ho fem. La nostra vida és una continua adaptació a les condicions de treball.

\section{D’on venim?: Treballadors flexibles i temporals}

En les darreres dècades aquesta adaptació ha estat vinculada a un procés de transformació del treball lligat als canvis en l'entorn socioeconòmic i cultural. Una transformació de gran envergadura en la que possiblement encara no s’hagi arribat a la seva màxima expressió.

La segona meitat del segle passat, època de grans canvis, va suposar que el món del treball, concretament les diferents formes d'ocupació i les seves condicions d'execució, es convertís en un dels principals problemes estructurals del model de creixement econòmic dels països europeus, que s'havia caracteritzat per un desenvolupament dèxit en els seus Estats del benestar.

La idea general d'un treball estable i de qualitat per tota la vida va anar desapareixent en favor d'una progressiva flexibilitat laboral que anava configurant un mercat segmentat amb diferents segments cada cop més inconnexos.

Les transformacions en el terreny productiu van facilitar que les empreses organitzessin el seu treball de forma més flexible. La flexibilitat productiva anava acompanyada per unes demandes empresarials en favor d'una flexibilitat laboral que facilités l'adaptació de les empreses als canvis a la vegada que facilitava l’adopció d'unes polítiques de contractació laboral més en sintonia amb els seus interessos de rendibilitat econòmica.

La contractació estable es va anar substituint per contractació temporal. La tipologia de contractes temporals s'anava diversificant en detriment del contracte indefinit. 
En el cas espanyol, la contractació temporal passa de ser una excepció a una generalització ${ }^{1} \mathrm{i}$ l'atur passa de ser un problema marginal a un dels esculls més importants tant en períodes de crisi com d'expansió econòmica. Ja als anys 80 i 90 la taxa d'atur va arribar al $22 \%$ en els trimestres de major penúria econòmica.

Com a conseqüència d'aquest procés ja abans de finalitzar el segle XX sociòlegs com C. Prieto y F. Miguélez $(1995,1999)^{2}$ parlaven de la crisi del treball com d'una crisi social, més enllà de les repercussions estrictament econòmiques.

Alguns analistes en matèria econòmica, com A. Recio (1988) i E. Cano (1996), centren la seva recerca en destacar els trets distintius de la precarietat en el treball. La flexibilitat laboral portada a la seva màxima expressió, com ha succeït a Espanya, i el conseqüent deteriorament de les condicions de treball aboquen a bona part de les persones treballadores a portar un estil de vida limitat, precari, amb dificultats de projecció vital com a conseqüència de situacions com els bai-

"El conseqüent deteriorament de les condicions de treball aboquen a bona part de les persones treballadores a portar un estil de vida limitat." xos salaris, les jornades de treball atípiques i la temporalitat en els seus contractes, entre altres ${ }^{3}$.

\section{Al segle XXI: Treballadors precaris i treballadors pobres}

A principis del segle XXI sorgeix el concepte de mileurista. Amb aquest terme es descriu a un important grup de població jove amb formació universitària, preparada, que parla idiomes i que amb dificultats aconsegueix una ocupació d’acord amb les seves aspiracions. A més, és remunerada sobre els mil euros mensuals circumstància amb la qual ha de sentir-se satisfeta, malgrat les limitacions en la seva qualitat de vida, perquè hi ha persones al seu voltant que estan pitjor.

1. La Llei 8/1980, de 10 de març, de l'Estatut dels treballadors 1980 establia el contracte indefinit com a norma i el temporal com a excepció. La reforma laboral Llei 32/1984 va impulsar el contracte temporal de foment a locupació ampliant-lo a qualsevol treballador desocupat i suprimint els topalls de contractació fixats en funció de la plantilla, pervertint la causalitat de la contractació.

2. C. Prieto i F. Miguélez coordinen els llibres Relaciones laborales en España (1995) i Relaciones de empleo en España (1999) publicats per l'editorial siglo XXI en el que diferents autors analitzen l'evolució de les relacions de treball a Espanya durant la segona meitat del segle XX.

3. E. Cano vincula la precarietat laboral amb les condicions de vida de les persones que la pateixen en el sentit d'identificar una situació de precarietat laboral amb la precarietat de vida. Amb aquest objectiu distingeix quatre dimensions de la precarietat com són: la inseguretat sobre l'ocupació en el treball, la insuficiència dels ingressos salarials, la degradació de la situació laboral i la manca de protecció social. Les quatre reflecteixen situacions generalitzades. 
A l'any 2013 Guy Standing (2013) identifica el precariat com una classe social que es caracteritza per la inconsistència $\mathrm{i}$ la feblesa dels mecanismes que garanteixen la seva subsistència. La persona precària és víctima de les polítiques d'austeritat i del progressiu debilitament de l'Estat del benestar, a un pas de l'exclusió social i de l'abisme de la pobresa.

Paral-lelament, abans de la crisi de l'any 2008, s'havia consolidat la figura del treballador pobre. La pobresa en el treball en l'actualitat passa a afectar a més d'un $10 \%$ de la població treballadora a Catalunya.

Lany 2012 s'aprova la Reforma Laboral (RDL 3/2012, de 10 de febrero) motivada, segons la seva exposició de motius, per reduir els efectes de la crisi sobre l'ocupació. Les principals conseqüències de l'aplicació d’aquesta reforma legislativa

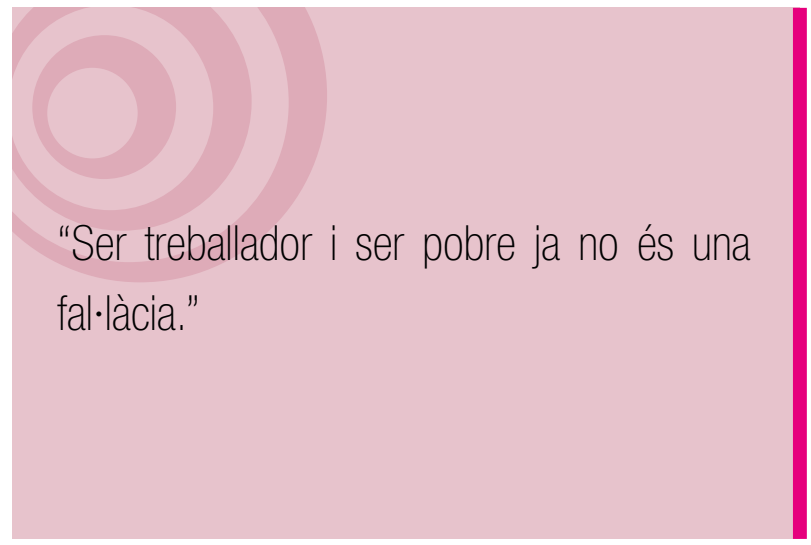

conseqüència de la millora econòmica que dels estímuls de l'esmentada reforma. Locupació és més inestable, menys segura i pitjor pagada (UGT, 2019).

En aquesta mateixa línia, A. Rivas (Rivas) destaca la visibilitat i el desvetllament del procés de precarització laboral i vital pel qual transiten treballadors i treballadores (Rivas, 2016). Es tracta d'una nova normalitat. Si l'ocupació fins al moment garantia la cobertura de les necessitats bàsiques de les persones i disposava d’un sistema de protecció social, la nova norma de l’ocupació és tot el contrari, no sols no garanteix els mínims per portar una vida digna sinó que s'ha convertit en un factor de vulnerabilitat i d’exclusió social. Ser treballador i ser pobre ja no és una fal-làcia.

\section{Breu radiografia del mercat de treball}

1. Desocupació: A Catalunya al 2019, segons l'INE, l'atur afecta al $11,3 \%$ de la població activa (unes 426.000 persones), entre aquesta, l'atur de llarga durada ( 1 any o més en cerca d’ocupació) afecta al 38,6\%. La taxa de cobertura per desocupació es troba en el 61\%. Paral-lelament, el nivell d'inactivitat representa un $38,4 \%$ de la població en edat de treballar (2.415.125 persones) de la qual un 57,6\% són dones. El nivell d’ocupació és del 54,7\%, un dels més baixos de 
la UE. Per tot plegat, al parlar de l'exclusió en el treball són diversos els colllectius de població a tenir en compte i diverses les circumstàncies que els afecten. Entre el conjunt de població, les taxes d'atur i d'inactivitat són: Dones (11,5\% i 43\%), població jove fins a 25 anys ( $26,2 \%$ i $54,8 \%$ ) i la major de 45 anys (9,3\% i 51,3\%), estrangers (18,5\% i 28,4\%) i els extracomunitaris $(21,6 \%$ i $37,2 \%)$, població amb baixa preparació $(15,7 \%$ i 52,6\%) i discapacitats $(23,1 \%$ i $65 \%)$

2. Temporalitat: A Catalunya, segons els registres del SOC, de la totalitat de contractes signats l'any 2018, el 86,1\% van ser contractes temporals. Líndex de rotació va ser del 2,5 (el que equival a dir que de mitjana cada persona contractada va signar entre 2 i 3 contractes). Per aquest mateix any, segons l'INE, la taxa de temporalitat se situava en el 21,9\% de la població assalariada.

3. Parcialitat: A Catalunya, segons els registres del SOC, de la totalitat de contractes signats l'any 2018 un $36,7 \%$ van ser a temps parcial. En el cas de les dones va ser un $45,7 \%$ mentre que entre els homes va ser un $28,5 \%$, majoritàriament temporals. Per aquest mateix any, segons l'INE, la taxa docupats a temps parcial és del 14,1\% de la població ocupada, d'un $22 \%$ en el cas de les dones. A nivell general el 54\% declaren fer-ho de forma involuntària pel fet de no trobar una ocupació a temps complet.

4. Baixos salaris: A Catalunya a més d'uns nivells salarials baixos existeix una elevada dispersió salarial. Segons dades de l'INE el salari brut mitjà anual l'any 2017 va ser de 25.180,45 euros. La població més jove guanya un 40,5\% del que guanya la de 55 anys o més i les dones un 77\% del que guanyen els homes. La població estrangera un $72,4 \%$ del que guanya l'espanyola i els treballadors d'ocupacions de baixa qualificació un 55,2\% de les d'alta qualificació. Aquest mateix any a Espanya un 13,6\% de les persones treballadores tenen guanys anuals de com a màxim el Salari Mínim Interprofessional, sent un 18,8\% en el cas de les dones.

5. Falsos autònoms: A Espanya, segons un informe d'ADECCO, el 41,7\% de les persones ocupades per compte propi (autònomes) ho són per necessitat i 7 de cada 10 professionals declaren que preferirien tenir un treball assalariat a jornada completa a mantenir la seva situació. Són molts els oficis que amb motiu de l'externalització de moltes activitats s'han convertit en ocupacions per compte pròpia, la majoria dels quals (un 65,8\% segons dades de l'INE a nivell estatal) els ocupen treballadors i treballadores independents sense persones assalariades al seu càrrec. La majoria treballen per a una sola empresa, amb el que perden la seva capacitat de decisió sobre la seva pròpia activitat.

6. Pobresa en el treball: Un dels indicadors que ha crescut més des de l'inici de la crisi del 2008 ha estat el percentatge de llars amb baixa intensitat en el treball que l'any 2018 es troba en el 5,8\% de les llars catalanes. Això explica el fet que a Catalunya la taxa de risc de pobresa en el treball se situï en el 14,4\% de la població treballadora, mentre que a la Unió Europea se situa en el $9,6 \%$. Aquesta és una de les raons que justifica que, segons l'ECV, les dificultats per arribar a final de mes ha augmentat entre les famílies catalanes.

7. Exclusió en el treball: Ja s'ha comentat en l'apartat sobre desocupació el percentatge de persones que no treballen i que per aquest motiu estan excloses del treball, que són les persones aturades i les inactives. Entre els dos grups un $45,8 \%$ de la població en edat de treballar cata- 
lana està exclosa del treball. Per aquest motiu en un 31,8\% de les llars catalanes no hi ha cap persona ocupada i, per tant, no tenen cap font d'ingressos procedents del treball.

\section{Quin model d'ocupació tenim?}

Totes aquestes situacions de treball i de no treball estan esteses per tot el territori català. Això posa de manifest que ha existit un insuficient impuls del creixement econòmic per la generació d’ocupació i que la que s'ha generat ha estat també insuficient per garantir la plena integració social per a un grup important de població.

A Catalunya - i al conjunt de l'estat espanyol — s'ha consolidat la segmentació laboral de manera que es distingeixen clarament les ocupacions que garanteixen estabilitat de les que no ho fan. Una de les manifestacions d'aquesta polarització

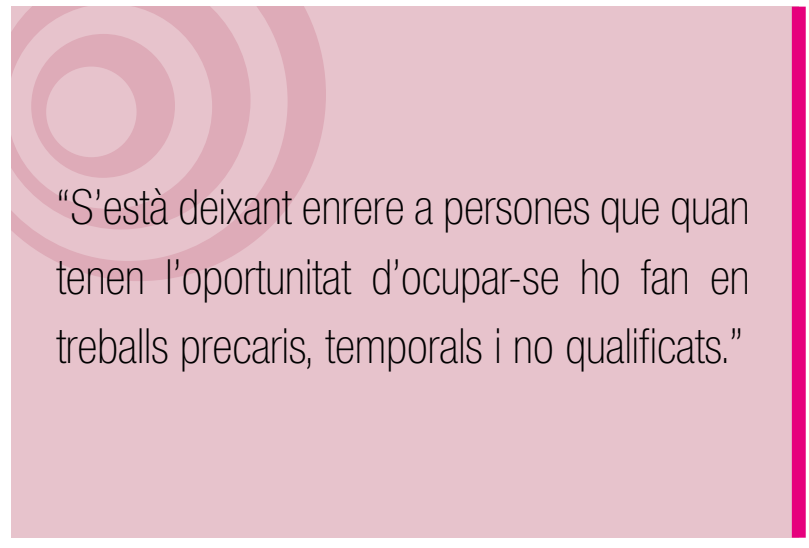

riors. Tanmateix, per algunes persones que es troben en el segment superior l'arribada d'una crisi pot traslladar-les de segment i trobar-se amb serioses dificultats de retorn al anterior.

S'està deixant enrere a persones abocades a la pobresa econòmica i a l'exclusió social, les quals quan tenen l'oportunitat d'ocupar-se ho fan en treballs precaris, temporals i no qualificats. Aquesta circumstància les manté en desavantatge. L'exclusió en l'ocupació i la inestabilitat de la mateixa es relacionen amb altres dimensions de l'exclusió social com l'educació, la salut o l'habitatge.

Aquests elements posen de manifest la necessitat de canviar el model docupació que tenim i de centrar-nos en alternatives que combinin polítiques d'ocupació ben encaminades, fent especial incidència en la qualificació, amb prestacions que compensin la situació de famílies en situació de dificultat derivada de la pobresa en el treball. En definitiva, polítiques que han d'atendre les noves realitats de fragilitat en el mercat de treball català que, a més, han de comptar amb una vocació d’adaptació a les noves situacions dels col-lectius de població més vulnerable, com aconsella FOESSA (Zugasti, 2019). 


\section{Referències}

Cano, E. (1996). El trabajo precario: concepto y dimensiones. In F. La Roca \& A. Sánchez (Eds.), Economía crítica, trabajo y medio ambiente. Valencia: Editorial Fundación de estudios e iniciativas sociolaborales de la Universitat de Valencia.

Miguélez Lobo, F., \& Prieto, C. (1995). Las relaciones laborales en España. Madrid: Siglo XXI de España Editores.

Miguélez Lobo, F., \& Prieto, C. (1999). Relaciones de empleo en España. Madrid: Siglo XXI de España Editores.

Real Decreto-ley 3/2012, de 10 de febrero, de medidas urgentes para la reforma del mercado laboral. Boletín Oficial del Estado, 11 de febrero de 2012, núm. 36 pp. 12483 a 12546.

Recio Andreu, A. (1988). Flexibilidad, eficiencia y desigualdad (notas sobre la flexibilidad laboral). Sociología del Trabajo(4), 81-106.

Rivas, A. M. (2016). Trabajo y pobreza. Cuando trabajar no es suficiente para vivir dignamente: Ediciones HOA.

Standing, G. (2013). El Precariado. Una nueva clase social: Pasado y Presente.

UGT. (2019). Los daños de la reforma laboral de 2012. Madrid.

Zugasti. (2019). ¿Hacia qué modelo de empleo nos estamos dirigiendo? Reflexiones sobre la pérdida de capacidad de integración del empleo en España. Madrid: Fundación FOESSA. 